\title{
Influence of Resilience on Survival of Small and Medium Enterprises
}

\author{
Owenvbiugie, Robinson Osarumwense ${ }^{\mathrm{a}}$ \\ ${ }^{a}$ Faculty of Education, Department of Vocational and Technical Education, University of Benin, Nigeria \\ Corresponding Author: osarumwense.owenvbiugie@uniben.edu
}

To cite this article (APA): Owenvbiugie, R. O. (2020). Influence of Resilience on Survival of Small and Medium Enterprises. International Business Education Journal, 13(1), 127-132. https://doi.org/10.37134/ibej.vol13.1.10.2020

To link to this article: https://doi.org/10.37134/ibej.vol13.1.10.2020

\begin{abstract}
The study assessed the influence of resilience skill for the survival of SMEs in Edo State. Two research questions guided the study, while research question two was hypothesized and tested. 236 respondents were used using a proportionate sampling technique from a population of 1117 business owners. This is $23.63 \%$ of the population. A descriptive survey was used. A reliability coefficient of 0.77 was obtained with the use of Cronbach alpha formula. Data were obtained with the aid of a questionnaire. The research question was answered with mean, while t-test for the hypothesis. From the result, it was discovered that resilience skill influences SMEs survival. The two groups of entrepreneurs used for the study did not show any significant difference in possession of resilience skill for SMEs survival. It was concluded that resilience skill is needed by entrepreneurs to a high extent. It was also concluded that males do not differ significantly from female entrepreneurs in possessing resilience skill for SMEs survival. Consequently, it was recommended that appraisal of SMEs operations should be on a consistent basis to check for lapses, make improvement and increase customers' goodwill, among others.
\end{abstract}

\section{Keywords:}

Resilience skill, SMEs survival, SMEs failure rate

\section{INTRODUCTION}

The issue of failure of small and medium enterprise has been in the front burner among business owners. However, researchers have diverse reasons why the failure rate of SMEs is high, but have not been able to proffer solutions to stop it. This gap seems to have existed for so long that new entrants are scared in establishing SMEs for the fear of attendant failures. This study tends to find out if resilience as a construct will be able to a large extent help reduce this scourge. Small and medium enterprises (SMEs) appear to be an essential instrument that pilots the desired development of any nation be it developed or developing. The development could be in the area of the creation of job as well as socio-economic emancipation. This is why Maas and Herrington (2006) stated that SMEs contribute substantially to the development of any nation's problem. Despite the shocking contribution of SMEs to the socio-economic development and its attendant performance, it appears that the expectation is falling below expectations in many developing countries including Nigeria. The SMEs seem to be bewildered by several factors hindering its performance, this making it to fail not too long after its establishment. These factors identified by Rahmad, Yaacob and Radzi (2016), Oboh (2002) and Okpan (2000) include the inability to access funds, government uncertain policies, as well as decayed facilities. 
Small and medium-sized enterprises appear to be the pillar that holds the development of a nation in the creation of employment and other ancillary services, all aimed at fostering growth and development as well as poverty alleviation. Udechukwu (2003) asserted that SMEs is fundamentally important to the overall growth and development of many economies including Nigeria. The parameter for ascertaining what constitutes small and medium-sized enterprises differs from country to country as well as one industry to another. Innovation, Science and Economic Development, Canada (2020) see a medium-sized business as one that has no fewer than 500 workers. Financial System Strategy (2020) sees SMEs as a business with a volume of sales that is less than N100 Million per annum and/ or less than 300 workers.

In spite of the enormous contributions of SMEs across the globe, the failure rate appears to be very high. This is why Mclntyre (2020) maintained that about $20 \%$ of small businesses in the United States of America fail in their first year, $30 \%$ of small businesses fail in their second year, and $50 \%$ of small businesses fail after five years in business. About $80 \%$ of businesses with employees will survive their first year in business. In Nigeria Alli and Jimoh (2013) said approximately 80 per cent of SMEs fail in Nigeria in their first five years of their establishment probably due to lack of business ineptitude. Watson (2003) pointed out that the reason for failures of SMEs may be as a result of ill-health of the respective owners. It appears that failures of SMEs seem to have defied all known solutions globally, will resilience be of help? Kendra (2019) sees resilience as how well people are able to deal with difficult times and come back with determined zeal. It can mean the ability to handle pressure without losing a sense of reasoning. People that are resilient tend to sustain a positive disposition in spite of vagaries of the business climate. Kendra further stated that people that are resilient are able to cope with business uncertainties. Instead of falling into a business coma, resilient people see the challenges as one that will spur them to find new opportunities. Youth Employment UK (2016) sees resilience as the capability to identify strengths in difficult situations. It means individuals who possess the skill of resilience may be capable of accepting criticism that will go a long way in resolving disputes in organizations. The specific objective of the study was to find out the influence of resilience on SMEs survival. Two research questions gave credence to the study: 1 . To what extent does resilience skill influence survival of SMEs? 2. To what extent does resilience skill influence male and female SMEs business owners in business survival? The second research question was hypothesized. Male entrepreneurs do not differ from female entrepreneurs in possession of resilience skill for business survival.

\section{METHODOLOGY}

A descriptive survey was employed in which data were collected with the aid of questionnaires as a tool for data collection. The population of this study consisted of one thousand one hundred and seventeen (1117) known SMEs owners in Edo State. The researcher obtained the list from the Nigerian Association of Small-Scale Industrialists (NASSI) office, Benin City branch. Proportionate sampling technique was used to select 236 respondents which were $23.63 \%$ of the population. The instrument was administered on a sample of 236 respondents distinct from those of the original study. A Cronbach alpha form of reliability was carried out and a reliability coefficient of 0.77 was obtained. 


\section{RESULTS AND DISCUSSION}

Mean and the standard deviation was used to answer the research question, while t-test statistics was used to test the hypothesis at an alpha level of $p<.05$

Table 1: Rating of resilience on survival of SMEs

\begin{tabular}{llll}
\hline S/N Item Statement & Mean (x) & SD & Remarks \\
\hline & & & \\
1. Remaining focused, even at difficult times & 2.88 & 1.01 & $\mathrm{HE}$ \\
2. Turning threats into opportunities & 2.92 & 1.02 & $\mathrm{HE}$ \\
3. Looking forward for the future & 2.96 & 1.05 & $\mathrm{HE}$ \\
4. Being inquisitive in learning & 2.85 & 0.91 & $\mathrm{HE}$ \\
5. Being able to develop with the passing times & 2.79 & 1.03 & $\mathrm{HE}$ \\
6. Being future-focus & 2.77 & 0.87 & $\mathrm{HE}$ \\
7. Having inner drive & 2.93 & 1.19 & $\mathrm{HE}$ \\
8. Being flexible in thinking & 2.87 & 0.92 & $\mathrm{HE}$ \\
9. Having strong relationship & 3.21 & 0.77 & $\mathrm{HE}$ \\
10. Being look innovative and creative & 3.43 & 0.61 & $\mathrm{HE}$ \\
11. Being able to evolve with the times & 2.97 & 1.04 & $\mathrm{HE}$ \\
12. Being able to be keep motivated at work & 2.61 & 1.06 & $\mathrm{HE}$ \\
13. Keeping motivated when something goes wrong & 3.72 & 0.53 & $\mathrm{HE}$ \\
14. Seeing change as normal as well as part of life & 3.76 & 0.52 & $\mathrm{HE}$ \\
15. Being able to fix mistakes then move on quickly & 2.85 & 0.89 & $\mathrm{HE}$ \\
16. Seeing problems as motivators & 2.75 & 1.02 & $\mathrm{HE}$ \\
17. Being able to ease on yourself when you make a mistake & & & \\
or get rejected & 2.52 & 1.12 & $\mathrm{HE}$ \\
18. Seeing problems as a challenge to be solved & 3.79 & 0.54 & $\mathrm{HE}$ \\
19. Having career and life goals you are committed to & 3.23 & 0.23 & $\mathrm{HE}$ \\
20. Being able to keeps friends in difficult times & 3.67 & 0.24 & $\mathrm{HE}$ \\
& & & \\
Grand $\quad$ Mean & $\mathbf{3 . 0 7}$ & $\mathbf{0 . 7 8}$ & HE \\
\hline
\end{tabular}

Based on Table 1, the variables (1-20) were rated high extent. The grand mean of 3.07 indicated that all the variables were rated high extent. The result shows that resilience skill is needed for the survival of SMEs to a high extent.

Table 2: Summary of t-test of male and female entrepreneurs

\begin{tabular}{llccccccc}
\hline Variable & Gender & N & Mean & SD & df & t-val & p-val & Dec \\
\hline & & & & & & & & \\
Resilience & Male & 202 & 18.89 & 4.533 & 2.62 & .074 & .941 & NS \\
Skill & Female & 62 & 18.96 & 3.931 & & & & \\
\hline
\end{tabular}

NS: Not significant 
Table 2 revealed that the t-value indicated .074 . The p-value showed 0.941 . The mean ratings of male and female entrepreneurs indicated 18.89 and 18.96 respectively. The standard deviation of male respondents showed 4.533 while that of female respondents indicated 3.931. The degree of freedom showed 2.62. On this note, male entrepreneurs do not differ from entrepreneurs on resilience skill for the survival of SMEs.

From the finding of the research question, resilience skill is needed by SMEs owners for the survival of their businesses to a high extent. This position is supported by Amanda (2017) who opined that SMEs owners are more likely to be interested in their dream jobs. They are more focused and less worried about failures. The researcher further said that resilient people are also nicer to be around - they bounce back quickly, do not involve in blaming others for their lapses and keep positive attitudes. Amanda (2017) further said that people that are resilient show a good example of positivity at all times more especially in difficult times having an answer to where they were in five years. This finding is consistent with Campbell (2017), Branicki, Sullivan-Taylor, and Livschitz (2018) and Nikolić, Jovanović, Nikolić, Mihajlović, and Schulte (2018) who maintained that resilient entrepreneurs hold the belief that nothing is impossible. Campbell further maintained that entrepreneurs do not lose hope, believing in possibility, and never losing a sense of humor. The researcher concluded that resilience gives entrepreneurs the hope of making it through difficult and challenging times.

The finding is also in consonance with Kendra (2019) who opined that even in challenging times that appear not permissible, resilience allows entrepreneurs to be hopeful of survival. The finding is also in agreement with Farrell (2019), Iborra, Safón, and Dolz (2019), Farradinna, Fadhlia, and Azmansyah (2019) and Fatoki (2018) who believed that through resilience skill, entrepreneurs possess the ability to bounce from tragedy, move on with others, and discover new opportunities. The finding is in contrast with ChamorroPremuzic and Lusk (2017) who maintained that over- dependence on resilience could make business owners remain resolute on goals that may not be attained. This leads to wasting of enormous time, effort and, resources in pursuing goals that may not be realized. The finding also contrasts Kaiser and Kaplan (2013) who opined that when business owners are allowed to overuse their strengths, it may lead to weaknesses. That is, when entrepreneurs are too resilient, it may lead to their own disadvantages. The finding is also in contrast with Mulqueen (2016) who stressed that people who are resilient are less creative and uses the same methods to achieve their goals over time.

\section{CONCLUSION}

It was concluded that the resilience skill influences the survival of SMEs positively in Edo State. The study further concluded that males SME owners do not differ from female SMEs owners in their possession of resilience skill for survival. The findings may be used to help business owners to stimulate their businesses. More knowledge is required about how business owners' resilience works and how it can be developed in the face of various challenges confronting businesses. Gaining access to real business owners was very challenging. This is an obvious limitation. The result of this study may not be used to generalize in entire Nigeria as only a few respondents were used. Further study is hereby needed in other parts of the country. It was recommended that SME owners should engage in periodic training for skills for SMEs survival; SMEs regulatory should ensure SMEs adhere to their mandate for customers' satisfaction and improve turn over; appraisal of SMEs 
operations should be on a consistent basis to check for lapses, make improvement and increase customers' goodwill; customers to demand bank core values and apply same when dealing the banks; and SMEs owners should provide a feedback mechanism that will allow customers to make constructive criticism of their operations for better service delivery.

\section{REFERENCES}

Alli, F. \& Jimoh, W. (2013). Eighty per cent of SMEs fail within 5 years - finance experts. Retrieved on 15th April 2020 from https://www.vanguardngr.com/2013/10/eightyper-cent-smes-fail-within-5-years-finance- experts/

Amanda, P. (2017). Resilience skills top of employers' wish list for new hires. Retrieved on $28^{\text {th }}$ December 2019 from https://www.careers.govt.nz/articles/resilience

Branicki, L. J., Sullivan-Taylor, B., \& Livschitz, S. R. (2018). How entrepreneurial resilience generates resilient SMEs. International Journal of Entrepreneurial Behavior \& Research, 24(7), 1244-1263.

Chamorro-Premuzic, T \& Lusk, D. (2017). The dark side of resilience. Retrieved on $13^{\text {th }}$ May 2020 from https://hbr.org/2017/08/the-dark-side-of-resilience

Campbell, S. (2017). The 8 magical benefits of resilience. Retrieved on $20^{\text {th }}$ April 2020 from https://www.entrepreneurs.com/article/289923

Farradinna, S., Fadhlia, T. N., \& Azmansyah, D. (2019). Psychological Resilience Predicted by Personality Traits, Locus of Control and Self-Regulation of Young Entrepreneurs in Pekanbaru. Global J. Bus. Soc. Sci. Review, 7(1), 106-113.

Farrell, L. (2019). The benefits of resilience training. Retrieved on $20^{\text {th }}$ April 2020 from https/trainingindustry.com/articles/compliance.

Fatoki, O. (2018). The impact of entrepreneurial resilience on the success of small and medium enterprises in South Africa. Sustainability, 10(7), 2527.

Financial System Strategy (2020). FSS 2020 international conference on SME: Issues, challenges and prospects. Retrieved on $15^{\text {th }}$ April 2020 from https://www.cbn.gov.ng/fss/wed/SME

Iborra, M., Safón, V., \& Dolz, C. (2019). What explains resilience of SMEs? Ambidexterity capability and strategic consistency. Long Range Planning, 101947.

Innovation, Science and Economic Development, Canada (2020). Departmental plan. Retrieved on $13^{\text {th }}$ April 2020 from https://www.ic.gc.ca/eic

Kaiser, R.B. \& Kaplan, R.E. (2013). Don't let your strengths become your weaknesses. Retrieved on $13^{\text {th }}$ May 2020 from https://hbr.org/2013/4

Kendra, C. (2019). What is resilience? Retrieved on $19^{\text {th }}$ April 2020 from https://www.verywellmind.com/what-is-resilience 
Maas, Gideon, Herrington, Mike. (2006). Global entrepreneurship monitor South African report. The UCT Center for Innovation and Entrepreneurship. Retrieved on $15^{\text {th }}$ April 2020 from http://www.gemconsortium.org/document.aspx?id756

Mclntyre, G (2020). What percentages of small businesses fail? (and other need-to-know stats). Retrieved on $15^{\text {th }}$ April 2020 from https://www.fundera.com/blog/whatpercentage-of-small-businesses-fail

Mulqueen, C. (2016). Are there cons to be resilient? Retrieved on $14^{\text {th }}$ May 2020 from https://tracom.com/blog/cons-resilient

Nikolić, N., Jovanović, I., Nikolić, Đ., Mihajlović, I., \& Schulte, P. (2018). Investigation of the factors influencing SME failure as a function of its prevention and fast recovery after failure. Entrepreneurship Research Journal, 9(3), 1-21.

Oboh, G.A.T. (2002). Bank participation in the promotion of small and mediumscale enterprises. Being a paper presented at the 6th Fellows and Associates Forum of CIBN on $13^{\text {th }}$ April, 2002.

Okpan FO (2000). Entrepreneurship (Text and Cases) Enugu Nigeria: Precision printers and publishers

Rahman, N. A., Yaacob, Z., \& Radzi, R. M. (2016). The challenges among Malaysian SME: A theoretical perspective. World, 6(3), 124-132.

Udechukwu, F.N. (2003). Survey of Small and Medium Scale Industries and their Potentials in Nigeria. Proc. Seminar on Small and Medium Industries Equity Investment Scheme (SMIEIS), Central Bank of Nigeria (CBN) Training Centre, Lagos, Nigeria, pp. 6-18. Technical Report.

Watson, J. (2003). Failure rate for female-controlled businesses: are they any different? Journal of Small Business Management, 41(3) : 262-27

Youth Employment UK (2016). Youth unemployment in the UK-The current picture. Retrieved on $13^{\text {th }}$ April 2020 from https://www.youthemployment.org.uk/dev/wpcontent/uploads/2016/05/UK 